\title{
Loss of D2 Dopamine Receptor Function Modulates Cocaine-Induced Glutamatergic Synaptic Potentiation in the Ventral Tegmental Area
}

\author{
Anuradha Madhavan, ${ }^{1,2}$ Emanuela Argilli, ${ }^{2}$ Antonello Bonci, ${ }^{2,3,4}$ and Jennifer L. Whistler ${ }^{1,2}$ \\ ${ }^{1}$ Ernest Gallo Clinic and Research Center, University of California San Francisco, Emeryville, California 94608, ${ }^{2}$ Department of Neurology, University of \\ California San Francisco, San Francisco, California 94143, ${ }^{3}$ Intramural Research Program, National Institute of Drug Abuse, Bethesda, Maryland 20892- \\ 9561, and ${ }^{4}$ Solomon H. Snyder Department of Neuroscience, The Johns Hopkins School of Medicine, Baltimore, Maryland 21287
}

Potentiation of glutamate responses is a critical synaptic response to cocaine exposure in ventral tegmental area (VTA) neurons. However, the mechanism by which cocaine exposure promotes potentiation of NMDA receptors (NMDARs) and subsequently AMPA receptors (AMPARs) is not fully understood. In this study we demonstrate that repeated cocaine treatment causes loss of D2 dopamine receptor functional responses via interaction with lysosome-targeting G-protein-associated sorting protein1 (GASP1). We also show that the absence of D2 downregulation in GASP1-KO mice prevents cocaine-induced potentiation of NMDAR currents, elevation of the AMPA/ NMDA ratio, and redistribution of NMDAR and AMPAR subunits to the membrane. As a pharmacological parallel, coadministration of the high-affinity D2 agonist, aripiprazole, reduces not only functional downregulation of D2s in response to cocaine but also potentiation of NMDAR and AMPAR responses in wild-type mice. Together these data suggest that functional loss of D2 receptors is a critical mechanism mediating cocaine-induced glutamate plasticity in VTA neurons.

\section{Introduction}

Acute and long-term exposure to cocaine, results in adaptations in both NMDA receptors (NMDAR) and AMPA receptors (AMPAR) in ventral tegmental area (VTA) neurons, which underlie many of the long-term synaptic and behavioral effects of cocaine (Saal et al., 2003). Specifically, acute cocaine ex vivo induces a potentiation of NMDAR excitatory postsynaptic currents (EPSCs), which is thought to result from an upregulation of NMDAR subunits, a postsynaptic effect (Schilström et al., 2006). This acute potentiation of NMDARs, in turn, leads to enhanced AMPAR subunit translocation, within 3-5 h after cocaine perfusion or in vivo injection, resulting in AMPAR potentiation and an elevated AMPA/NMDA ratio (Ungless et al., 2001; Saal et al., 2003; Borgland et al., 2004; Argilli et al., 2008). However, the precise mechanisms by which cocaine, whose primary target is the dopamine transporter (Giros et al., 1991; Kilty et al., 1991), modulates glutamate receptors remains unclear.

\footnotetext{
Received Feb. 21, 2013; revised June 11, 2013; accepted June 18, 2013.

Author contributions: A.M., A.B., and J.W. designed research; A.M. and E.A. performed research; A.M., A.B., and J.W. contributed unpublished reagents/analytic tools; A.M. analyzed data; A.M. and J.W. wrote the paper.

A.M. was supported by a National Alliance for Research on Schizophrenia and Depression Young Investigator Award and received salary support from a National Institutes of Health National Research Service Award F32 postdoctoral Fellowship (5F32DA027286-02). J.L.W. was supported by grants from the National Institute of Drug Abuse (R01 DA019958-05 and R21 MH096058-01) and by funds provided by the State of California for medical research on alcohol and substance abuse through the University of California San Francisco. We thank Madeline Ferwerda for maintenance and genotyping of mouse colonies and Dawn Thompson for assisting with cocaine injections in preliminary experiments.

Correspondence should be addressed to Jennifer L. Whistler, Ernest Gallo Clinic and Research Center, 5858 Horton Street, Suite \#200, Emeryville, CA 94608. E-mail: Jennifer.Whistler@ucsf.edu.

DOI:10.1523/JNEUROSCI.0809-13.2013

Copyright $\odot 2013$ the authors $\quad 0270-6474 / 13 / 3312329-08 \$ 15.00 / 0$
}

The initial cocaine-induced NMDA potentiation has been proposed to occur as a consequence of cocaine-induced somatodendritic dopamine release (Zhang et al., 1994; Adell and Artigas, 2004) followed by activation of the D1-like D5 dopamine receptors, and stimulation of the CAMP-PKA pathway (Schilström et al., 2006). However, VTA neurons express not only the $G_{s}$ coupled D5 dopamine receptor but also $\mathrm{G}_{\mathrm{i}}$-coupled D2 receptors (Boyson et al., 1986; Mercuri et al., 1997; Ciliax et al., 2000; Khan et al., 2000). This may be particularly relevant for cAMP-PKAdependent glutamatergic plasticity since D5 and D2 dopamine receptors have opposing effects on the cAMP-protein kinase A (PKA) pathway (Missale et al., 1998). By extension, since changes in PKA activity modulate NMDAR potentiation, perturbations in the balance of these two dopamine receptor types would be expected to have an effect on glutamatergic synaptic plasticity in this brain region.

Following activation by dopamine, the D5 dopamine receptor undergoes endocytosis and recycling (Thompson and Whistler, 2011), while the D2-type dopamine receptors are endocytosed and degraded through their interaction with the G-proteinassociated sorting protein 1 (GASP1; Bartlett et al., 2005). This postendocytic sorting of D2 receptors by GASP1 has recently been shown to be critical for cocaine-mediated downregulation of D2 receptors in vivo (Thompson et al., 2010). Here we examined whether postendocytic downregulation of D2 receptors contributes to cocaine-mediated NMDAR and AMPAR potentiation in VTA neurons. We demonstrate that preventing the loss of D2 receptors, either in mice with a disruption of the GASP1 gene, or using aripiprazole (Abilify), a high-affinity D2 agonist that does not induce endocytosis and degradation of the D2 receptors 
(Thompson et al., 2010), plays a critical role in mediating cocaineinduced changes in glutamate synaptic plasticity in VTA neurons.

\section{Materials and Methods}

\section{Subjects}

Experiments were performed on male mice aged between postnatal days 23 and 28. The C57-Black/6 GASP1-KO mice and their wild-type (WT) littermates were bred as described previously (Thompson et al., 2010). All mice were bred in-house and procedures were performed in accordance with Institutional Animal Care and Use Committee guidelines at the Ernest Gallo Clinic and Research Center.

\section{Electrophysiology}

WT and GASP1-KO mice were injected only daily in their home cages with saline or cocaine $(15 \mathrm{mg} / \mathrm{kg}$, i.p.) or cocaine and aripiprazole (15 $\mathrm{mg} / \mathrm{kg}$, i.p. each). Horizontal brain slices of the VTA were prepared $24 \mathrm{~h}$ after mice received the last intraperitoneal injection of saline or cocaine. The mice were anesthetized with $5 \%$ isoflurane and immediately decapitated using a guillotine. Brain slices $190 \mu \mathrm{m}$ thick were cut in ice-cold modified artificial CSF ( $\mathrm{aCSF}$ ) solution. All solutions were saturated with $95 \% \mathrm{O}_{2}-5 \% \mathrm{CO}_{2}$ (carbogen). The composition of the solution contained the following (in mM): 85 choline $\mathrm{Cl}, 40 \mathrm{NaCl}, 4 \mathrm{KCl}, 1.25 \mathrm{NaH}_{2} \mathrm{PO}_{4}, 25$ $\mathrm{NaHCO}_{3}, 0.5 \mathrm{CaCl}_{2}, 7 \mathrm{MgCl}_{2}, 10$ dextrose, 1 ascorbate, $3 \mathrm{Na}$ pyruvate, and 3 myo inositol; osmolarity: 310-320. Slices were recovered first for $\sim 10-15 \mathrm{~min}$ at $32^{\circ} \mathrm{C}$ in the cutting solution and were later transferred to recording aCSF of the following composition (in $\mathrm{mm}$ ): $125 \mathrm{NaCl}, 2.5 \mathrm{KCl}$, $1.25 \mathrm{NaH}_{2} \mathrm{PO}_{4}, 1 \mathrm{MgSO}_{4}, 2 \mathrm{CaCl}_{2}, 25$ dextrose, and $25 \mathrm{NaHCO}_{3}$; 295300 osmolarity. Glutamate currents were recorded in the presence of picrotoxin $(100 \mu \mathrm{M})$ to block $\mathrm{GABA}_{\mathrm{A}}$ receptors.

Cells were visualized using an upright microscope with infrared illumination. We used an Axopatch 200 Amplifier (Molecular Devices) to perform whole-cell patch-clamp recordings with 2-6 M $\Omega$ electrodes containing the following (in $\mathrm{mM}$ ): 120 cesium methanesulfonic acid, 20 HEPES, 0.4 EGTA, 2.8 NaCl, 5 TEA-Cl, 2.5 NaATP, and 0.25 NaGTP, pH 7.2-7.4. The VTA neurons that were recorded in this study were characterized by the presence of $\mathrm{I}_{\mathrm{h}}$, a current found in $>98 \%$ of mouse VTA dopamine neurons (Wanat et al., 2008; Madhavan et al., 2010). A bipolar stimulating electrode was placed $100-300 \mu \mathrm{m}$ rostral to the recording electrode and afferents were stimulated at $0.1 \mathrm{~Hz}$. The evoked EPSCs were filtered at $2 \mathrm{kHz}$, digitized at $5-10 \mathrm{kHz}$, and recorded using Igor Pro software (WaveMetrics). We held neurons at $+40 \mathrm{mV}$ for recordings of NMDA-mediated EPSCs. AP-5 (50 $\mu \mathrm{M})$ was used to block NMDARs, while recording AMPA/NMDA ratios. Data were averaged in $2.5 \mathrm{~min}$ bins, normalized to baseline, which is defined as the average EPSC amplitude of $10 \mathrm{~min}$ before drug application, and presented as average across cells \pm SEM. The magnitude of the enhancement of the NMDAREPSCs during 30 consecutive sweeps taken 25-30 min after washout of the drug was used for comparison between groups. For long-term potentiation (LTP) experiments, evoked EPSPs were recorded from neurons current clamped at -65 to $-70 \mathrm{mV}$ using 3-5 $\mathrm{M} \Omega$ electrodes filled with a potassium gluconate solution containing the following (in $\mathrm{mM}$ ): 115 potassium gluconate, $5 \mathrm{HEPES}, 0.1 \mathrm{EGTA}, 20 \mathrm{NaCl}, 1.5 \mathrm{MgCl}_{2}, 2 \mathrm{NaATP}$, and $0.5 \mathrm{~mm}$ NaGTP, pH 7.3. LTP was induced by using a spike timingdependent (STD) protocol where 20 bursts of EPSP-spike pairs were delivered, with each burst consisting of five paired stimuli delivered at 10 $\mathrm{Hz}$ (interburst interval of $5 \mathrm{~s}$ ) (Argilli et al., 2008). The postsynaptic spikes were evoked $\sim 5 \mathrm{~ms}$ after the onset of EPSPs by injecting depolarizing current pulses (1-2 nA, $3 \mathrm{~ms}$ ).

To record the effect of quinpirole on G-protein-coupled inwardly rectifying $\mathrm{K}^{+}$(GIRK) conductances, the potassium methanesulfonatebased internal solution consisted of $0.95 \%(\mathrm{v} / \mathrm{v}) \mathrm{KOH}, 0.38 \%(\mathrm{v} / \mathrm{v})$ methanesulfonic acid, 20 m MEPES, 0.2 mm EGTA, $2.8 \mathrm{~mm} \mathrm{NaCl}, 2.5$ $\mathrm{mg} / \mathrm{ml} \mathrm{NaATP}$, and $0.25 \mathrm{mg} / \mathrm{ml} \mathrm{NaGTP}$, pH 7.2-7.4, osmolarity 275285 . Neurons were visualized with an upright microscope equipped with infrared differential interference contrast using Axiovision camera and software (Carl Zeiss Microimaging). aCSF at $30-32^{\circ} \mathrm{C}$ was continuously perfused at $2-3 \mathrm{ml} / \mathrm{min}$ over brain slices.

Synaptosomal membrane preparation and Western blotting. VTA brain tissue was extracted from WT or GASP1-KO mice treated with saline or cocaine (15 mg/kg, i.p.), $24 \mathrm{~h}$ after the last injection. The tissue was homogenized manually in an ice-cold buffer containing $10 \mathrm{~mm}$ Trisacetate, $5 \mathrm{~mm}$ EDTA, $0.32 \mathrm{~m}$ sucrose, and protease and phosphatase inhibitor I and II. The homogenate was centrifuged at $1000 \times g$ for $10 \mathrm{~min}$ at $4^{\circ} \mathrm{C}$ to pellet heavy membranes and debris (P1). The supernatant $(\mathrm{S} 1)$ was collected and centrifuged at $16,000 \times g$ at $4^{\circ} \mathrm{C}$ for $20 \mathrm{~min}$ to pellet the synaptosomal membrane fraction (P2). P2 was resuspended and protein concentration was estimated. Protein $(20 \mu \mathrm{g})$ was resolved by NuPage $4-12 \%$ Bis-Tris gel and transferred to a PVDF membrane. Membranes were probed with the appropriate antibodies to NMDAR subunits: NR1 (mouse anti-NR1; Millipore, 1:500), NR2B (rabbit anti-NR2B; Millipore, 1:1000), NR2A (rabbit anti-NR2A; Cell Signaling Technology, 1:1000); AMPAR subunit: GLUA1 (mouse anti-Glur1; Santa Cruz Biotechnology, 1:500), and $\beta$-actin (mouse anti- $\beta$-actin; Sigma, 1:20,000). Secondary antibodies used were the IRDye $800 \mathrm{CW}$ goat anti-rabbit or anti-mouse (LI-COR Biosciences, 1:15,000). The LI-COR Odyssey system was used for fluorescent imaging and quantification of the Western blots.

Data analysis. Data analysis was performed using GraphPad Prism or Microsoft Excel. Data are represented as mean \pm SEM, unless specified; $t$ tests or one-way ANOVA was used to compare data for significance ${ }^{* * *} p<0.001,{ }^{* *} p<0.01 ;{ }^{*} p<0.05$; ns $\left.p>0.05\right)$.

\section{Results}

\section{Cocaine induces loss of D2 dopamine receptor response in VTA neurons}

Application of a saturating dose of quinpirole ( $3 \mu \mathrm{M})$, a D2-type dopamine receptor agonist, induces activation of a hyperpolarizing potassium (GIRK) conductance in VTA neurons (Fig. $1 A, D$; peak effect in WT: $18.97 \pm 2.07 \mathrm{mV}, n=5)$. Treatment of WT mice with cocaine $(15 \mathrm{mg} / \mathrm{kg}, 5 \mathrm{~d}$, once daily) resulted in a significant reduction in the activation of this GIRK conductance by quinpirole (Fig. 1A,D; peak effect in WT cocaine: $7.58 \pm 0.66$ $\mathrm{mV}, n=5$; comparing with WT: $p=0.0008$; $\left.t_{(1,8)}=5.24\right)$ suggesting that repeated treatment with cocaine induces a loss in the functional effect of D2 dopamine receptors in VTA neurons.

We next examined the effects of repeated cocaine on D2 receptor function in mice with a genetic disruption of GASP1 (GASP1-KO). Quinpirole induced a GIRK conductance in VTA neurons from the GASP1-KO mice indistinguishable from that in WT mice (Fig. $1 B, D$; peak effect in GASP1-KO: $20.34 \pm 2.01 \mathrm{mV}$, $n=5$; comparing with WT: $\left.p=0.65 ; t_{(1,8)}=0.48\right)$. However, repeated cocaine treatment produced a significantly reduced loss of D2 responses in GASP-KO mice. (Fig. 1C,D; peak effect in GASP1-KO cocaine: $13.04 \pm 1.05 \mathrm{mV}, n=5$; with WT cocaine: $\left.p=0.002 ; t_{1,8)}=4.41\right)$. Thus, the functional effects of $\mathrm{D} 2$ receptors are likely to be maintained in the GASP1-KOs even after repeated cocaine. This is supported by biochemical evidence of both in vitro and in vivo downregulation of D2 dopamine receptors likely mediated, at least in part, by an interaction of the receptors with GASP1 (Bartlett et al., 2005; Thompson et al., 2010).

\section{Absence of cocaine-induced NMDA potentiation in GASP1-KO mice}

Cocaine perfusion in VTA slices induces a PKA-dependent timedelayed potentiation of NMDA EPSCs, a response that has been shown to require activation of the $\mathrm{G}_{\mathrm{s}}$-coupled D5 receptor (Schilström et al., 2006). However, the role of the $\mathrm{G}_{\mathrm{i}}$-coupled D2-type dopamine receptors and, in particular, whether functional loss of D2 receptors, which occurs in a time course consistent with the delay in potentiation, was important for the potentiation has not been examined. Perfusion of cocaine $(5 \mu \mathrm{M})$ resulted in a delayed potentiation of NMDA EPSCs (Fig. $2 A, C$; percentage NMDA potentiation in WT (gray bar): $136.81 \pm 14.26, n=11$ ) as previ- 


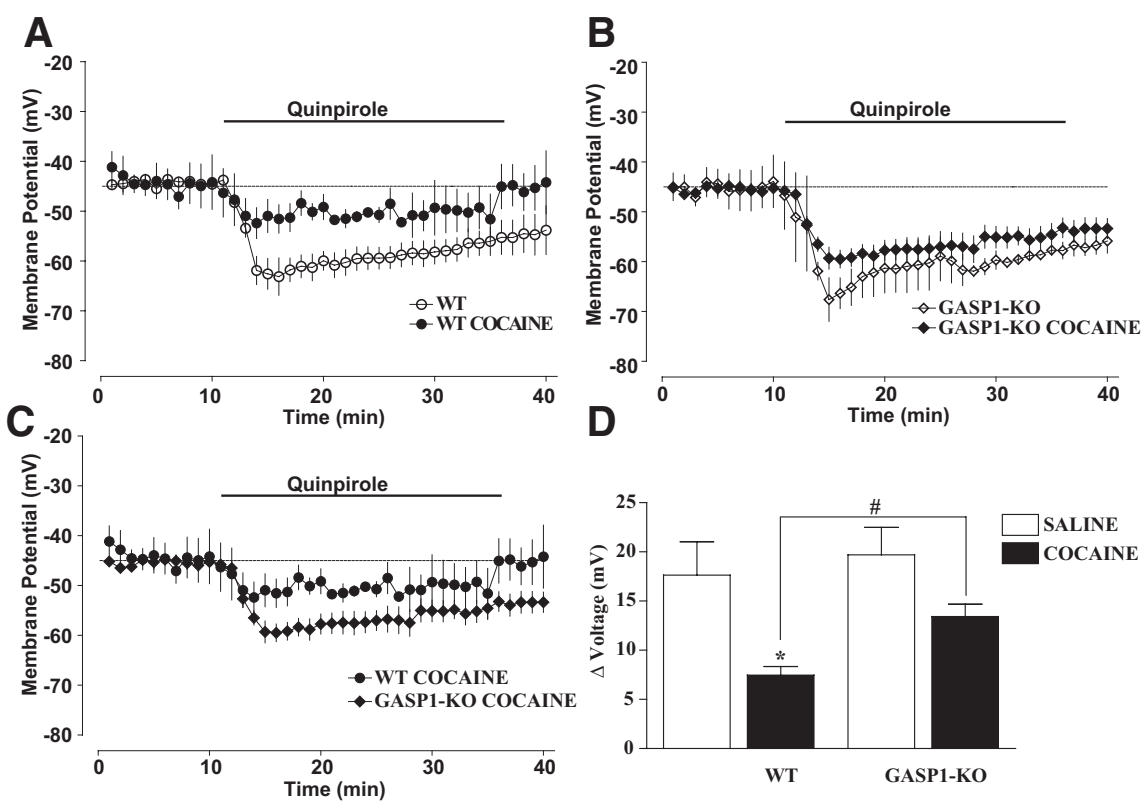

Figure 1. Rescue of cocaine-induced functional loss of $D 2$ dopamine receptor responses in GASP1-KO. A, D2 agonist quinpirole $(3 \mu \mathrm{m})$ perfusion induces activation of GIRK conductance in WT after saline or cocaine treatment $(15 \mathrm{mg} / \mathrm{kg}$, i.p., once daily, $5 \mathrm{~d})$. Activation of GIRK conductance is significantly reduced in WT after repeated cocaine treatment. $\boldsymbol{B}$, Quinpirole perfusion induces activation of GIRK conductance in GASP1-K0 after saline or cocaine treatment ( $15 \mathrm{mg} / \mathrm{kg}$, i.p., once daily, $5 \mathrm{~d}$ ). C, Comparison of quinpirole-activated GIRK conductance in repeated cocaine-treated WT and GASP1-KO mice. D, Bar graph showing maximal activation of GIRK conductance, demonstrates that repeated cocaine induces a loss of D2-activated GIRK in WT but not in GASP1-KO (peak effect in WT: $18.97 \pm 2.07 \mathrm{mV}$; WT cocaine:7.58 \pm 0.66 mV; GASP1-K0: $20.35 \pm 2.01 \mathrm{mV}$; GASP1-K0 cocaine: $13.04 \pm 1.05$ $\mathrm{mV} ; n=5$ each). ${ }^{\#} p<0.05,{ }^{*} p<0.05$.

ously reported. Repeated cocaine treatment in vivo produced a greater elevation in the potentiation induced by cocaine in vitro (Fig. $2 A, C$; percentage NMDA potentiation in WT cocaine (gray bar): $174.02 \pm 7.78, n=8$; comparing with WT: $p=0.055 ; t_{(1,17)}=$ $2.06)$, suggesting that cocaine-induced loss of $\mathrm{D} 2$ receptors could enhance cocaine-mediated NMDAR potentiation. However, treatment of WT mice with quinpirole ( $5 \mathrm{mg} / \mathrm{kg}$, i.p., $1 \mathrm{~d}$ ), was not sufficient to exacerbate the in vitro cocaine-induced potentiation of NMDA EPSCs (Fig. $2 A, C$; percentage NMDA potentiation in WT quinpirole (gray bar): $144.4 \pm 7.77, n=5$; comparing with WT: $\left.p=0.74 ; t_{(1,14)}=0.34\right)$. Together, we find that while loss of D2 receptor function is necessary to produce cocaineinduced NMDA potentiation, it is not sufficient to do so.

Potentiation of NMDARs in response to cocaine in the VTA slice is thought to occur via a rearrangement of NMDAR subunit composition in these neurons (Schilström et al., 2006). Specifically, cocaine has been shown to produce an increased synaptic expression of both the obligatory NR1 subunit and the NR2B subunit (Schilström et al., 2006). Here, we likewise found that repeated cocaine produced a significant increase in NR1, NR2B, and NR2A levels in WT mice (Fig. $2 D, E$; percentage change WT cocaine; NR1: $159.4 \pm 13.81, n=8, p=0.004 ; t_{(1,7)}=4.3$; NR2B: $250.8 \pm 42.63, n=12, p=0.005 ; t_{(1,11)}=3.54$; NR2A: $193.6 \pm$ $\left.30.55, n=8, p=0.02 ; t_{(1,7)}=3.06\right)$.

Next, we examined whether removal of GASP1 altered cocaine-induced NMDAR potentiation. Perfusion of cocaine did not produce a potentiation of NMDA EPSCs in GASP1-KO mice, neither in naive mice, nor in mice pretreated with repeated cocaine (Fig. $2 B, C$; percentage NMDA EPSC in GASP1-KO (gray bar): $90.29 \pm 9.25, n=12$; WT vs GASP1-KO: $p=0.011 ; t_{(1,21)}=$ 2.78; percentage NMDA EPSC in GASP1-KO cocaine: $68.3 \pm$ 10.47, $n=6$; WT vs GASP1-KO cocaine: $p=0.005 ; t_{(1,15)}=$
3.26). Furthermore, in the GASP1-KO mice, cocaine treatment did not produce significant changes in the NR1 and NR2B subunit expression, and produced a decrease rather than an increase in NR2A expression (Fig. 2F, G; percentage change GASP1-KO cocaine; NR1: $73.55 \pm 14.85$, $n=6, p=0.14 ; t_{(1,5)}=1.78$; NR2B: $103.1 \pm$ $12, n=8, p=0.8 ; t_{(1,7)}=0.26$; NR2A: $\left.75.55 \pm 5.71, n=6, p=0.008 ; t_{(1,5)}=4.28\right)$, consistent with the observed lack of NMDA potentiation by cocaine in GASP1-KO mice. Reducing the functional downregulation of D2 receptors in response to cocaine prevents changes in NMDAR function associated with cocaine exposure.

\section{Absence of AMPAR potentiation in cocaine-treated GASP1-KO mice} Cocaine-induced changes in NMDA subunit composition have been shown to result in a cascade of events that produce reciprocal potentiation of AMPA EPSCs that is measured as an elevated AMPA/ NMDA ratio (Argilli et al., 2008). Changes in AMPA/NMDA ratio are time locked to the cocaine-induced changes in NMDAR, as they are blocked by the NMDAR antagonist AP-5 (Argilli et al., 2008). An increase in the AMPA/NMDA ratio is thought to underlie long-term synaptic and behavioral responses to cocaine (Chen et al., 2008). Thus, we examined the effect of repeated cocaine treatment on AMPA/ NMDA ratios in both WT and GASP1-KO mice. We observed a significant elevation in AMPA/NMDA ratios in WT mice after repeated cocaine treatment (Fig. $3 A, B, E$; AMPA/NMDA WT saline: $0.43 \pm 0.11, n=5$; AMPA/NMDA WT cocaine: $1.39 \pm 0.15$, $\left.n=4 ; p=0.001 ; t_{(1,7)}=5.19\right)$. This effect on the AMPA/NMDA ratio is thought to be mediated by an increased insertion of the AMPAR subunit GLUA1 after cocaine (Huang et al., 2009; Lüscher and Malenka, 2011). Consistent with this hypothesis, repeated cocaine resulted in a significant elevation in GLUA1 receptor expression in the VTA (Fig. 3F,G; percentage change WT cocaine; GLUA1: $210.1 \pm 28.32, n=12, p=0.002$; $\left.t_{(1,11)}=3.89\right)$.

In contrast, in GASP1-KO mice, there was no elevation in AMPA/NMDA ratio after repeated cocaine (Fig. 3C-E; AMPA/ NMDA GASP1-KO saline: $0.98 \pm 0.17, n=6$; AMPA/NMDA GASP1-KO cocaine: $\left.0.78 \pm 0.15, n=4 ; p=0.43 ; t_{(1,8)}=0.84\right)$. Furthermore, cocaine did not produce an increase in GLUA1 subunit expression in GASP1-KO mice. In fact, we observed a reduction in GLUA1 subunit expression levels in these mice after repeated cocaine (Fig. $3 \mathrm{H}$, I percentage change GASP1-KO cocaine; GLUA1: $\left.68.21 \pm 3.98, n=8, p<0.0001 ; t_{(1,7)}=7.98\right)$, consistent with the trend toward a decrease in the AMPA/NMDA ratio after repeated cocaine in the GASP1-KO mice.

These data further support the view that cocaine-induced NMDA potentiation drives a reciprocal elevation in AMPA/ NMDA. Furthermore, since neither of these adaptive changes occurs in GASP1-KO mice, these data indicate that functional downregulation of $\mathrm{D} 2$ receptors is a trigger for the adaptations in glutamate receptor responsiveness and subunit specification on VTA neurons. 
A

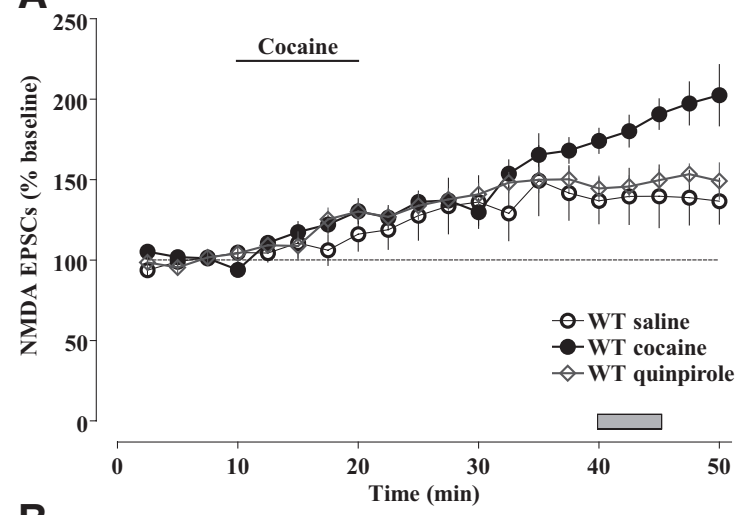

B
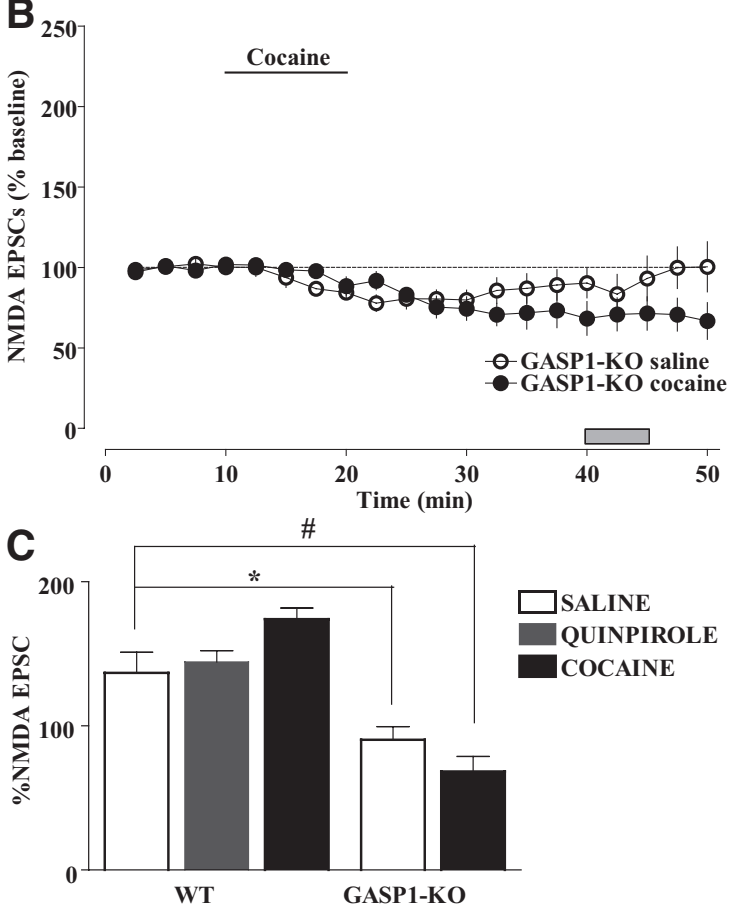

D

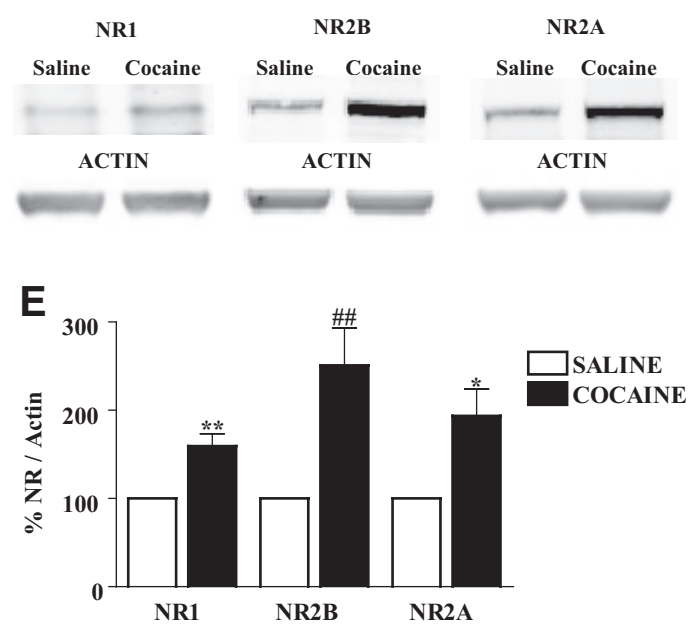

$\mathbf{F}$
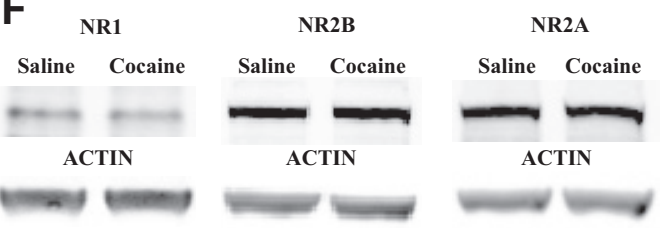

G

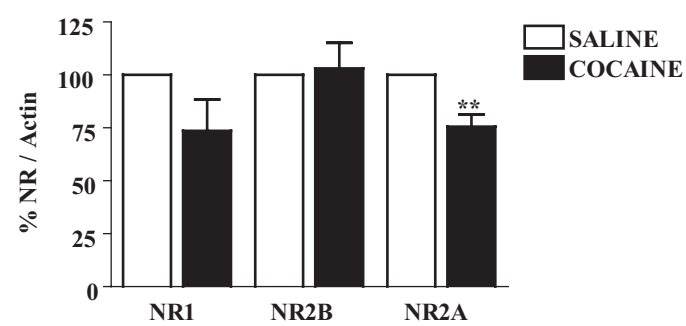

Figure 2. Absence of cocaine-induced NMDA potentiation in GASP1-K0. $A$, Cocaine ( $5 \mu \mathrm{m})$ perfusion results in potentiation of NMDAR EPSCs in WT after saline, single quinpirole, and repeated cocaine treatment. $B$, Cocaine perfusion does not induce a potentiation of NMDA EPSCs in GASP1-K0 after saline or repeated cocaine treatment. $C$, Bar graph showing effect of cocaine perfusion on NMDA EPSCs in WT and GASP1-KO (data extracted from gray bar in $\boldsymbol{A}$ and $\boldsymbol{B}$ ) demonstrates that cocaine perfusion results in potentiation of NMDA EPSC in WT but not in GASP1-K0 after saline or cocaine treatment (percentage NMDA potentiation in WT: $136.81 \pm 14.26, n=11$; WT cocaine: 174.02 $\pm 7.78, n=8$; GASP1-K0: $90.29 \pm 9.25, n=12 ;$ GASP1-K0 cocaine: 68.3 $\pm 10.47, n=$ 6). D, Western blots of NMDAR subunits NR1, NR2B, and NR2A in a synaptosomal preparation of the WT VTA. $\boldsymbol{E}$, NR1, NR2B, and NR2A expression levels are significantly increased in WT after repeated cocaine treatment (percentage change from 100\% in WT to WT cocaine; NR1: $159.4 \pm 13.81, n=8$; NR2B: $250.8 \pm 42.63, n=12$; NR2A: 193.6 $\pm 30.55, n=8$ ). $\boldsymbol{F}$, Western blots of NMDAR subunits NR1, NR2B, and NR2A in a synaptosomal preparation of the GASP1-KO VTA. G, NR1 and NR2B expression levels are unchanged after cocaine in GASP1-K0 and NR2A expression levels are significantly reduced repeated cocaine treatment (percentage change from 100\% in GASP1-K0 to GASP1-K0 cocaine; NR1: 73.55 $\pm 14.85, n=6 ; \mathrm{NR2B}: 103.1 \pm 12, n=8 ;$ NR2A: 75.55 \pm 5.71, $n=6) .{ }^{\#} p<0.05,{ }^{*} p<0.05,{ }^{* *} p<0.01$, and ${ }^{\# \#} p<0.01$.

\section{STD LTP induction occurs in WT and GASP1-KO}

We next examined whether the lack of cocaine-mediated changes in the AMPA/NMDA ratio was a consequence of the somewhat higher baseline levels of AMPARs (Fig. 3C). Specifically, we tested whether the higher levels of AMPARs at baseline in the GASP1-KO occludes further potentiation by recording STD LTP induction in both WT and GASP1-KO VTA neurons. WT VTA neurons showed robust STD LTP induction (Fig. 4A,C; $154 \pm$ $18.8 \%$ at the $30-35$ min time points, $n=6$ cells). GASP1-KO VTA neurons also showed robust STD LTP induction (Fig. $4 B, D$; $147.6 \pm 9.5 \%$ at the $30-35$ min time points, $n=6$ cells), which was not significantly different from WT STD LTP induction ( $p=$ $\left.0.77, t_{(1,10)}=0.3\right)$. Consequently the lack of cocaine-induced potentiation in GASP1-KO mice is unlikely a consequence of synaptic occlusion.
D2 dopamine receptor downregulation underlies cocaineinduced changes in glutamate EPSCs

GASP1 controls the postendocytic sorting of several G-proteincoupled receptors. Thus, to specifically address whether maintenance of functional D2 receptors in the GASP1-KO mice was responsible for preventing cocaine-induced changes in glutamate responses, we used an alternative pharmacological strategy. Aripiprazole is a high-affinity partial agonist at the D2 dopamine receptors approved for human use as an atypical antipsychotic and antidepressant (Lawler et al., 1999; Mazza et al., 2009; Shelton et al., 2010). Aripiprazole activates $G_{i}$ signaling from D2 receptors and has an affinity for the D2 receptor nearly 500 -fold higher than dopamine (Burris et al., 2002). However, aripiprazole-activated D2 receptors are not recruited for endocytosis or downregulated due to their inability to induce significant 
A

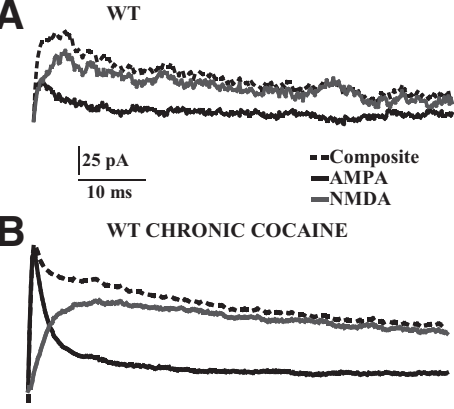

C
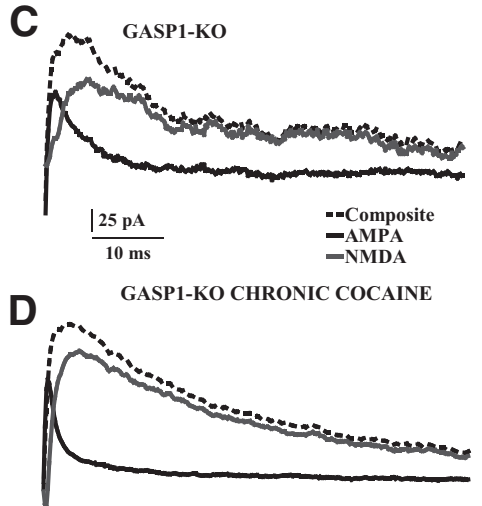

E

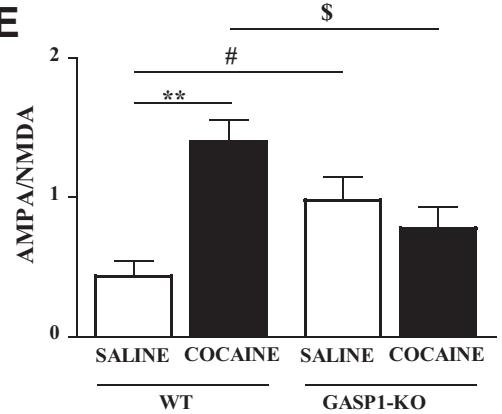

$\mathbf{F}$
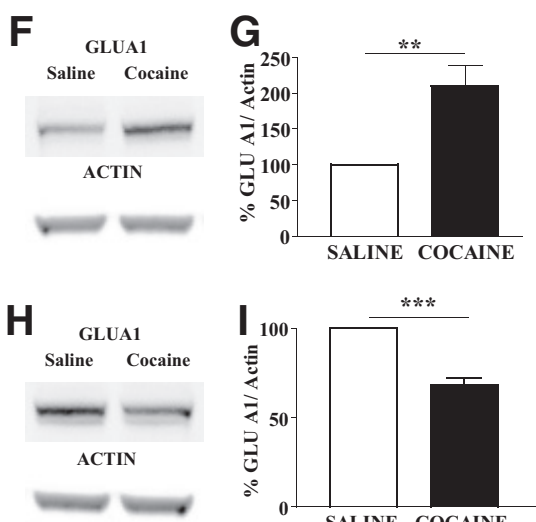

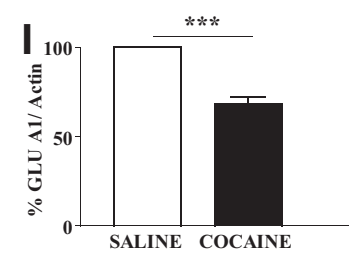

Figure 3. Absence of AMPAR potentiation in cocaine-treated GASP1-KO. A-D, AMPA and NMDA EPSCs in WT and GASP1-KO after saline and repeated cocaine treatment. $E$, AMPA/ NMDA ratios are elevated after repeated cocaine treatment in WT but not in GASP1-KO (WT saline: $0.43 \pm 0.11, n=5$; WT cocaine: $1.39 \pm 0.15, n=4$; GASP1-KO saline: $0.98 \pm$ $0.17, n=6$; GASP1-K0 cocaine: $0.78 \pm 0.15, n=4$ ). $\boldsymbol{F}$, Western blot of AMPAR GLUA1 subunit in a synaptosomal membrane preparation of the WT VTA. G, GLUA1 expression level is significantly elevated after repeated cocaine treatment in WT (percentage change from 100\% in WT to WT cocaine; GLUA1: $210.1 \pm 28.32, n=12$ ). $\boldsymbol{H}$, Western blot of AMPAR GLUA1 subunit in a synaptosomal membrane preparation of the GASP1-KO VTA. I, GLUA1 expression level is significantly reduced after repeated cocaine treatment in GASP1-KO (percentage change from 100\% in GASP1-K0 to GASP1-KO cocaine; GLUA1: $68.21 \pm 3.98, n=8) .{ }^{*} p<0.05,{ }^{5} p<0.05,{ }^{* *} p<0.01$, and ${ }^{* * *} p<0.001$.

A
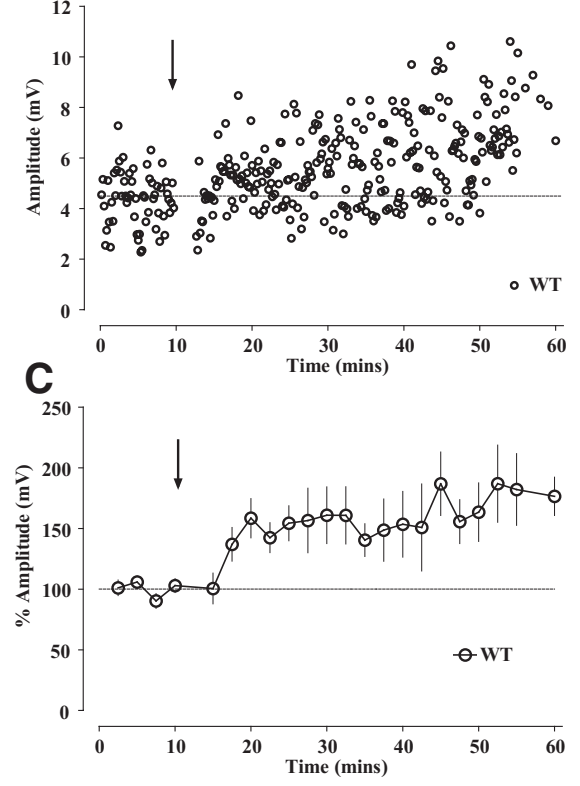

B
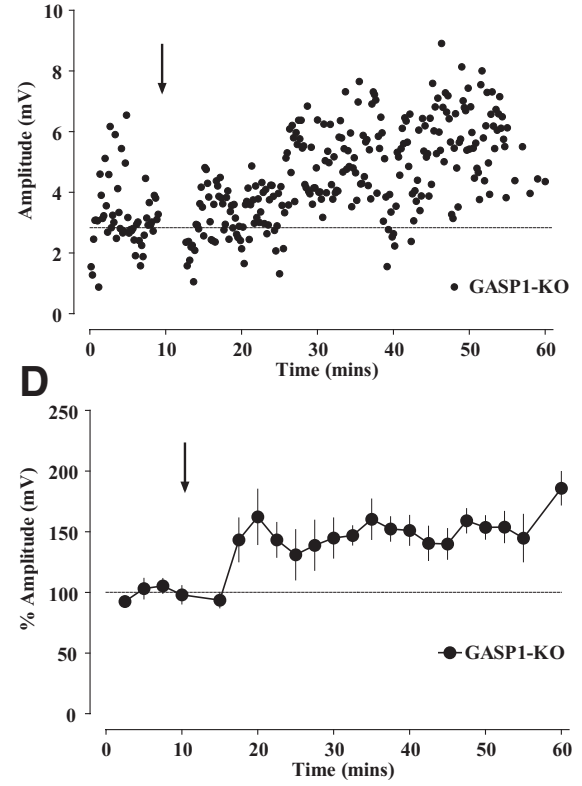

Figure 4. STD LTP induction occurs in WT and GASP1-KO. $\boldsymbol{A}, \boldsymbol{B}$, Raw traces of EPSPs showing STD LTP induction in WT and GASP1-K0 VTA neurons, respectively. $\boldsymbol{C}, \boldsymbol{D}$, Time course of average EPSPs in WT and GASP1-KO VTA neurons (percentage amplitude of induction: WT: $154 \pm 18.8 \mathrm{mV} \%, n=6 ;$ GASP1-K0: $\left.147.6 \pm 9.5 \mathrm{mV} \%, n=6, p=0.77, t_{(1,10)}=0.3\right)$.

$\beta$-arrestin recruitment (Klewe et al., 2008; Masri et al., 2008; Allen et al., 2011). We hypothesized that coapplication of aripiprazole with cocaine would maintain $G_{i}$ signaling through D2 receptors but prevent their functional downregulation in response to cocaine.

Indeed, we found that repeated treatment with a mixture of aripiprazole and cocaine $(15 \mathrm{mg} / \mathrm{kg}$ each for $5 \mathrm{~d}$, once daily) prevented the functional downregulation of D2-GIRK responses in VTA neurons (Fig. 5A; peak effect in WT cocaine + aripiprazole: $15.07 \pm 2.18 \mathrm{mV}$, $n=5$; comparing with WT cocaine: $p=$ $\left.0.01 ; t_{(1,8)}=3.29\right)$. Furthermore, coapplication of aripiprazole $(5 \mu \mathrm{M})$ and cocaine $(5 \mu \mathrm{M})$, did not result in a potentiation of NMDA EPSCs that was observed with cocaine alone (compared with WT cocaine: $\left.p<0.0001 ; t_{(1,12)}=8.83\right)$. Instead, coapplication of aripiprazole and cocaine had a significant depressive effect on the NMDA EPSCs compared with saline (Fig. 5B; percentage NMDA potentiation in WT cocaine + aripiprazole (gray bar): $89.95 \pm$ $\left.13.72, n=6 ; p=0.048, t_{(1,15)}=2.14\right)$. Most importantly, repeated treatment with cocaine and aripiprazole $(15 \mathrm{mg} / \mathrm{kg}$ each for $5 \mathrm{~d}$, once daily), did not induce an elevation of AMPA/NMDA responses, in contrast to repeated cocaine alone (Fig. 5C; AMPA/ NMDA WT cocaine + aripiprazole: $0.89 \pm$ $\left.0.10, n=7 ; p=0.02 ; t_{(1,9)}=2.82\right)$. In contrast, repeated treatment of mice with cocaine and quinpirole $(15 \mathrm{mg} / \mathrm{kg}$ cocaine and $5 \mathrm{mg} / \mathrm{kg}$ quinpirole for $5 \mathrm{~d}$, once daily), a D2 agonist that does drive D2 receptor downregulation (Thompson et al., 2010), produced a substantial potentiation of the AMPA/NMDA (Fig. 5D; AMPA/NMDA WT cocaine + quinpirole: $3.18 \pm 1.06, n=$ 6; comparing with WT cocaine + aripiprazole: $p=0.04 ; t_{(1,11)}=2.34$; comparing with WT cocaine: $\left.p=0.21 ; t_{(1,8)}=1.35\right)$.

Together, we show evidence that reducing cocaine-mediated loss of the D2 receptor responses, using a biased D2 receptor agonist that does not promote D2 receptor endocytosis, has equivalent protective effects for preventing cocaineinduced glutamatergic synaptic plasticity as the genetic disruption of GASP1.

\section{Discussion}

In this study, we have demonstrated a critical role of D2 dopamine receptor loss in mediating cocaine-induced synaptic potentiation of AMPAR and NMDAR EPSCs in VTA neurons. This loss of D2 receptors is likely mediated by postendocytic degradation by GASP1 binding, since both disruption of GASP1 and pre- 
vention of D2 receptor endocytosis by aripiprazole prevent the cocaine-induced changes in glutamatergic potentiation.

These cocaine-induced changes in glutamate potentiation are thought to play a critical role in the development of behaviors associated with cocaine abuse and addiction (Bowers et al., 2010; Lüscher and Malenka, 2011). Indeed, pharmacological blockade of NMDARs in the VTA prevents the acquisition of locomotor sensitization and conditioned place preference (CPP) to cocaine (Kalivas and Alesdatter, 1993; Harris and Aston-Jones, 2003). Additionally, removal of functional NMDARs from dopamine neurons in the VTA also impairs cocaine CPP (Zweifel et al., 2008). Changes in NMDA potentiation modulate AMPAR function and subunit upregulation, in an NMDAR-dependent fashion, resulting in an increase in AMPA/NMDA ratio or AMPAR potentiation (Argilli et al., 2008). Elevation of the AMPA/NMDA ratio, a cellular hallmark of drug abuse, occurs both during passive cocaine exposure and active self-administration, and is thought to orchestrate long-term synaptic plasticity in response to cocaine (Ungless et al., 2001; Chen et al., 2008).

Our goal in these studies has been to identify the cellular mechanisms mediating cocaine-induced changes in glutamate receptors. Cocaine exposure is thought to result in a local increase in dopamine levels around the soma of VTA neurons (Zhang et al., 1994), which is worsened by inefficient reuptake processes in the presence of cocaine (Iravani et al., 1996). Prior evidence indicated a critical role of cAMPPKA signaling from the D1-type, D5 dopamine receptor for the changes in NMDA and AMPA function after cocaine exposure in the VTA. Nevertheless, VTA neurons express not only dopamine D5 but also D2 receptors, which have opposing effects on PKA activity. Furthermore, D2 dopamine receptors present on the cell bodies of VTA neurons also likely modulate the action potential duration in these neurons (Margolis et al., 2008). Thus, it is reasonable to hypothesize that $\mathrm{D} 2$ receptor signaling could also be an important modulator of cocaineinduced glutamate plasticity. In fact, the D2 antagonist eticlopride, when coapplied with cocaine, results in an earlier rise time for NMDA potentiation and a marginal increase in amplitude of the responses (Schilström et al., 2006) suggesting that activity at D2 opposes the action at D5.

Indeed, one of the most well established molecular hallmarks of drug abuse is a loss of dopamine D2 receptor availability (Chen et al., 1993; Moore et al., 1998; Jones et al., 1999; Attarbaschi et al., 2007). However, the molecular mechanisms responsible for downregulation of D2 receptors and the consequences of this downregulation for cellular physiology have remained unclear. ${ }^{* *} p<0.01$.
B

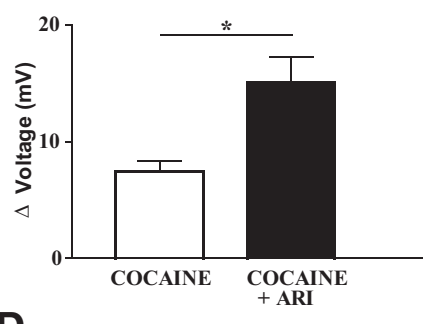

D

Quinpirole
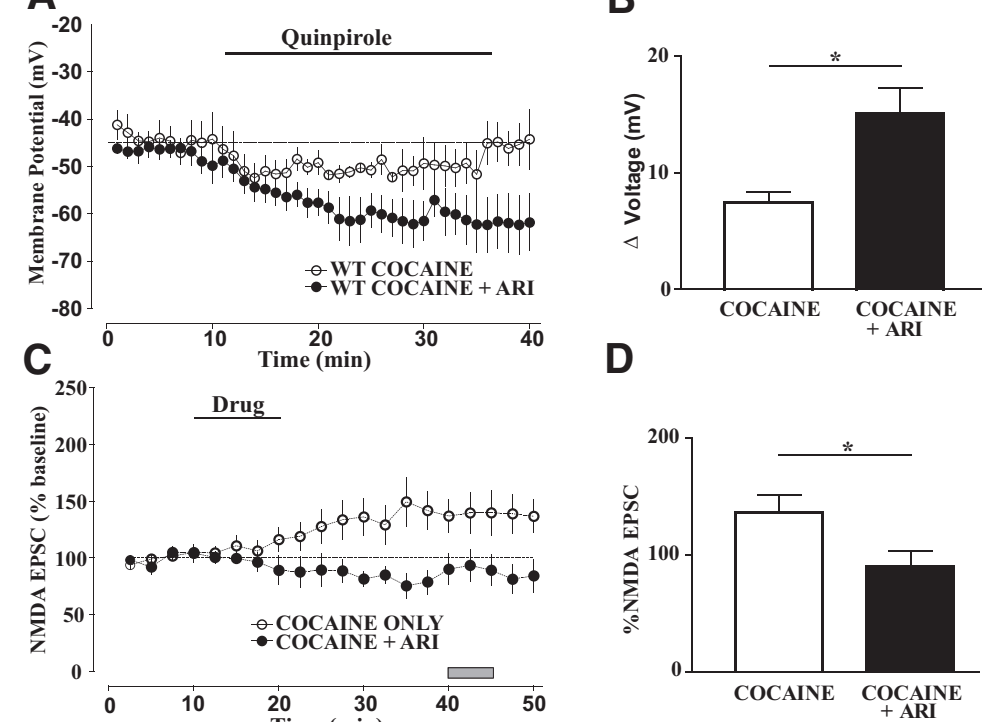

$\mathbf{F}$

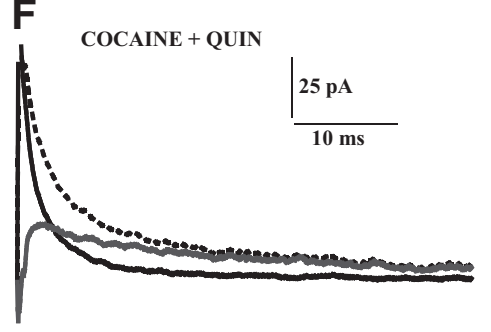

Figure 5. Loss of D2 dopamine receptor function underlies cocaine-induced changes in NMDAR and AMPAR potentiation. $A$, Quinpirole (QUIN)-activated GIRK conductance is not substantially reduced after repeated cocaine and aripiprazole (ARI) treatment in WT. B, Bar graph showing maximal activation of QUIN-induced GIRK conductance after cocaine and ARI treatment in WT shows a significant increase in peak activation compared with treatment with cocaine alone (peak effect in WT cocaine: $7.58 \pm 0.66 \mathrm{mV}$; WT cocaine + ARl: $15.07 \pm 2.18 \mathrm{mV}, n=5$ each). C, Absence of NMDAR EPSC potentiation after coperfusion of cocaine $(5 \mu \mathrm{M})$ and ARI $(5 \mu \mathrm{M})$ in WT. D, Bar graph showing effect of cocaine and cocaine plus ARI coperfusion on NMDA EPSCs in WT (percentage NMDA in WT mice treated with cocaine and ARI (15 mg/kg each, once daily, 5 d) (WT cocaine: $1.39 \pm 0.15, n=4$; WT cocaine + ARI: $0.89 \pm 0.10, n=7) . F$, AMPA and NMDA EPSCs in WT mice treated with cocaine and QUIN ( $15 \mathrm{mg} / \mathrm{kg}$ cocaine and $5 \mathrm{mg} / \mathrm{kg}$ QUIN reduced compared with cocaine-treated WTs but elevated after cocaine and QUIN treatment in WT. ${ }^{*} p<0.05,{ }^{\#} p<0.05$, and

D2-type dopamine receptors are targeted for degradation in the lysosome after endocytosis through their interaction with GASP1 both in vitro and in vivo (Bartlett et al., 2005; Thompson et al., 2010) and GASP1-KO mice do not show cocaine-induced downregulation of D2 receptors. Importantly, GASP1-KO mice also show reduced locomotor sensitization to cocaine (Thompson et al., 2010), a reduction in acquisition of cocaine self-administration (Boeuf et al., 2009) and deficits in motivation (Mathis et al., 2011). Together, these data suggest that D2 receptor hypofunction is important for diverse behavioral effects of cocaine.

In this study we provide mechanistic insight into how functional downregulation of D2-type dopamine receptors after re- 
peated cocaine exposure could affect drug-induced behavior. We hypothesized that loss of D2 receptors through postendocytic degradation, and the consequent change in the balance of D5 and D2 signaling, would be necessary for cocaine-induced glutamatergic plasticity. We show that, in the absence of GASP1, D2 receptors in the VTA are not substantially downregulated functionally. We further show that maintenance of D2 receptor signaling prevents cocaine-induced NMDA potentiation, increases in the AMPA/NMDA ratio, and the concomitant increases in NMDA and AMPA subunit expression levels. Importantly, we show that the GASP1-KO synapses are not prepotentiated or occluded to further potentiation, as the induction of STD LTP in these synapses are not significantly different compared with WT synapses.

Together these data suggest that loss of D2 receptor function is necessary to produce cocaine-induced changes in glutamatergic plasticity. Nevertheless, it is clear that signaling from D5 receptors is also necessary, since pretreatment with quinpirole, a D2 receptor agonist, does not result in a sizable increase in the cocaine-induced NMDA EPSCs compared with saline-treated mice. In short, our studies suggest that restoration of the balance of D2 and D1 signaling prevents changes in glutamatergic plasticity that accompanies chronic drug use. We used two methods to maintain D2 receptor levels, one genetic-the GASP1 KO mice, and one pharmacological - using the noninternalizing high-affinity D2 receptor agonist aripiprazole, which has been shown recently to block cue-conditioned and cocaine-primed reinstatement of cocaine seeking (Feltenstein et al., 2007). Importantly, the effects of aripiprazole on cocaine-induced plasticity were not replicated by cotreatment with quinpirole, another high-affinity D2 receptor agonist that does induce endocytosis and loss of D2 receptors. Thus, preventing the loss of D2 receptors, not merely providing tone through D2 receptors, was necessary to block cocaine-induced glutamatergic plasticity. The GASP1-D2 interaction could be a novel target for the treatment of drug abuse. Additionally, the efficacy and safety profile of aripiprazole for disease indications including schizophrenia and depression may reflect its ability to restore the balance of D2 and D1 signaling, by providing agonist tone through $\mathrm{D} 2$ receptors without causing their downregulation. In this way, aripiprazole is not merely a substitute for dopamine or D2 agonists such as quinpirole, which do cause D2 downregulation. In conclusion, here we identify a molecular mechanism, GASP1-mediated downregulation of D2 dopamine receptors, which is responsible, at least in part, for drug-induced changes in glutamatergic plasticity in dopamine neurons of the VTA. Identifying this mechanism not only provides insight into why drug abusers of all kinds show low D2 receptor availability, but also highlights the potential utility of an FDA-approved pharmacological agent that could prove to be useful in the treatment of drug abuse.

\section{References}

Adell A, Artigas F (2004) The somatodendritic release of dopamine in the ventral tegmental area and its regulation by afferent transmitter systems. Neurosci Biobehav Rev 28:415-431. CrossRef Medline

Allen JA, Yost JM, Setola V, Chen X, Sassano MF, Chen M, Peterson S, Yadav PN, Huang XP, Feng B, Jensen NH, Che X, Bai X, Frye SV, Wetsel WC, Caron MG, Javitch JA, Roth BL, Jin J (2011) Discovery of beta-arrestinbiased dopamine D2 ligands for probing signal transduction pathways essential for antipsychotic efficacy. Proc Natl Acad Sci U S A 108:1848818493. CrossRef Medline

Argilli E, Sibley DR, Malenka RC, England PM, Bonci A (2008) Mechanism and time course of cocaine-induced long-term potentiation in the ventral tegmental area. J Neurosci 28:9092-9100. CrossRef Medline

Attarbaschi T, Sacher J, Geiss-Granadia T, Klein N, Mossaheb N, Lanzen- berger R, Asenbaum S, Dudczak R, Kasper S, Tauscher J (2007) Striatal $\mathrm{D}(2)$ receptor occupancy in bipolar patients treated with olanzapine. Eur Neuropsychopharmacol 17:102-107. CrossRef Medline

Bartlett SE, Enquist J, Hopf FW, Lee JH, Gladher F, Kharazia V, Waldhoer M, Mailliard WS, Armstrong R, Bonci A, Whistler JL (2005) Dopamine responsiveness is regulated by targeted sorting of D2 receptors. Proc Natl Acad Sci U S A 102:11521-11526. CrossRef Medline

Boeuf J, Trigo JM, Moreau PH, Lecourtier L, Vogel E, Cassel JC, Mathis C, Klosen P, Maldonado R, Simonin F (2009) Attenuated behavioural responses to acute and chronic cocaine in GASP-1-deficient mice. Eur J Neurosci 30:860-868. CrossRef Medline

Borgland SL, Malenka RC, Bonci A (2004) Acute and chronic cocaineinduced potentiation of synaptic strength in the ventral tegmental area: electrophysiological and behavioral correlates in individual rats. J Neurosci 24:7482-7490. CrossRef Medline

Bowers MS, Chen BT, Bonci A (2010) AMPA receptor synaptic plasticity induced by psychostimulants: the past, present, and therapeutic future. Neuron 67:11-24. CrossRef Medline

Boyson SJ, McGonigle P, Molinoff PB (1986) Quantitative autoradiographic localization of the D1 and D2 subtypes of dopamine receptors in rat brain. J Neurosci 6:3177-3188. Medline

Burris KD, Molski TF, Xu C, Ryan E, Tottori K, Kikuchi T, Yocca FD, Molinoff PB (2002) Aripiprazole, a novel antipsychotic, is a high-affinity partial agonist at human dopamine D2 receptors. J Pharmacol Exp Ther 302:381-389. CrossRef Medline

Chen BT, Bowers MS, Martin M, Hopf FW, Guillory AM, Carelli RM, Chou JK, Bonci A (2008) Cocaine but not natural reward self-administration nor passive cocaine infusion produces persistent LTP in the VTA. Neuron 59:288-297. CrossRef Medline

Chen JF, Aloyo VJ, Weiss B (1993) Continuous treatment with the D2 dopamine receptor agonist quinpirole decreases D2 dopamine receptors, D2 dopamine receptor messenger RNA and proenkephalin messenger RNA, and increases mu opioid receptors in mouse striatum. Neuroscience 54: 669-680. CrossRef Medline

Ciliax BJ, Nash N, Heilman C, Sunahara R, Hartney A, Tiberi M, Rye DB, Caron MG, Niznik HB, Levey AI (2000) Dopamine D(5) receptor immunolocalization in rat and monkey brain. Synapse 37:125-145. CrossRef Medline

Feltenstein MW, Altar CA, See RE (2007) Aripiprazole blocks reinstatement of cocaine seeking in an animal model of relapse. Biol Psychiatry 61:582590. CrossRef Medline

Giros B, el Mestikawy S, Bertrand L, Caron MG (1991) Cloning and functional characterization of a cocaine-sensitive dopamine transporter. FEBS Lett 295:149-154. CrossRef Medline

Harris GC, Aston-Jones G (2003) Critical role for ventral tegmental glutamate in preference for a cocaine-conditioned environment. Neuropsychopharmacology 28:73-76. CrossRef Medline

Huang YH, Lin Y, Mu P, Lee BR, Brown TE, Wayman G, Marie H, Liu W, Yan Z, Sorg BA, Schlüter OM, Zukin RS, Dong Y (2009) In vivo cocaine experience generates silent synapses. Neuron 63:40-47. CrossRef Medline

Iravani MM, Muscat R, Kruk ZL (1996) Comparison of somatodendritic and axon terminal dopamine release in the ventral tegmental area and the nucleus accumbens. Neuroscience 70:1025-1037. CrossRef Medline

Jones SR, Gainetdinov RR, Hu XT, Cooper DC, Wightman RM, White FJ, Caron MG (1999) Loss of autoreceptor functions in mice lacking the dopamine transporter. Nat Neurosci 2:649-655. CrossRef Medline

Kalivas PW, Alesdatter JE (1993) Involvement of N-methyl-D-aspartate receptor stimulation in the ventral tegmental area and amygdala in behavioral sensitization to cocaine. J Pharmacol Exp Ther 267:486-495. Medline

Khan ZU, Gutiérrez A, Martín R, Peñafiel A, Rivera A, de la Calle A (2000) Dopamine D5 receptors of rat and human brain. Neuroscience 100:689699. CrossRef Medline

Kilty JE, Lorang D, Amara SG (1991) Cloning and expression of a cocainesensitive rat dopamine transporter. Science 254:578-579. CrossRef Medline

Klewe IV, Nielsen SM, Tarp ø L, Urizar E, Dipace C, Javitch JA, Gether U, Egebjerg J, Christensen KV (2008) Recruitment of beta-arrestin2 to the dopamine D2 receptor: insights into anti-psychotic and antiparkinsonian drug receptor signaling. Neuropharmacology 54:12151222. CrossRef Medline 
Lawler CP, Prioleau C, Lewis MM, Mak C, Jiang D, Schetz JA, Gonzalez AM, Sibley DR, Mailman RB (1999) Interactions of the novel antipsychotic aripiprazole (OPC-14597) with dopamine and serotonin receptor subtypes. Neuropsychopharmacology 20:612-627. CrossRef Medline

Lüscher C, Malenka RC (2011) Drug-evoked synaptic plasticity in addiction: from molecular changes to circuit remodeling. Neuron 69:650-663. CrossRef Medline

Madhavan A, He L, Stuber GD, Bonci A, Whistler JL (2010) micro-Opioid receptor endocytosis prevents adaptations in ventral tegmental area GABA transmission induced during naloxone-precipitated morphine withdrawal. J Neurosci 30:3276-3286. CrossRef Medline

Margolis EB, Mitchell JM, Ishikawa J, Hjelmstad GO, Fields HL (2008) Midbrain dopamine neurons: projection target determines action potential duration and dopamine $\mathrm{D}(2)$ receptor inhibition. J Neurosci 28:8908-8913. CrossRef Medline

Masri B, Salahpour A, Didriksen M, Ghisi V, Beaulieu JM, Gainetdinov RR, Caron MG (2008) Antagonism of dopamine D2 receptor/beta-arrestin 2 interaction is a common property of clinically effective antipsychotics. Proc Natl Acad Sci U S A 105:13656-13661. CrossRef Medline

Mathis C, Bott JB, Candusso MP, Simonin F, Cassel JC (2011) Impaired striatum-dependent behavior in GASP-1-knock-out mice. Genes Brain Behav 10:299-308. CrossRef Medline

Mazza M, Squillacioti MR, Pecora RD, Janiri L, Bria P (2009) Effect of aripiprazole on self-reported anhedonia in bipolar depressed patients. Psychiatry Res 165:193-196. CrossRef Medline

Mercuri NB, Saiardi A, Bonci A, Picetti R, Calabresi P, Bernardi G, Borrelli E (1997) Loss of autoreceptor function in dopaminergic neurons from dopamine D2 receptor deficient mice. Neuroscience 79:323-327. CrossRef Medline

Missale C, Nash SR, Robinson SW, Jaber M, Caron MG (1998) Dopamine receptors: from structure to function. Physiol Rev 78:189-225. Medline

Moore RJ, Vinsant SL, Nader MA, Porrino LJ, Friedman DP (1998) Effect of cocaine self-administration on dopamine D2 receptors in rhesus monkeys. Synapse 30:88-96. CrossRef Medline

Saal D, Dong Y, Bonci A, Malenka RC (2003) Drugs of abuse and stress trigger a common synaptic adaptation in dopamine neurons. Neuron 37:577-582. CrossRef Medline

Schilström B, Yaka R, Argilli E, Suvarna N, Schumann J, Chen BT, Carman M, Singh V, Mailliard WS, Ron D, Bonci A (2006) Cocaine enhances NMDA receptor-mediated currents in ventral tegmental area cells via dopamine D5 receptor-dependent redistribution of NMDA receptors. J Neurosci 26:8549-8558. CrossRef Medline

Shelton RC, Osuntokun O, Heinloth AN, Corya SA (2010) Therapeutic options for treatment-resistant depression. CNS Drugs 24:131-161. CrossRef Medline

Thompson D, Whistler JL (2011) Trafficking properties of the D5 dopamine receptor. Traffic 12:644-656. CrossRef Medline

Thompson D, Martini L, Whistler JL (2010) Altered ratio of D1 and D2 dopamine receptors in mouse striatum is associated with behavioral sensitization to cocaine. PLoS One 5:e1 1038. CrossRef Medline

Ungless MA, Whistler JL, Malenka RC, Bonci A (2001) Single cocaine exposure in vivo induces long-term potentiation in dopamine neurons. Nature 411:583-587. CrossRef Medline

Wanat MJ, Hopf FW, Stuber GD, Phillips PE, Bonci A (2008) Corticotropin-releasing factor increases mouse ventral tegmental area dopamine neuron firing through a protein kinase C-dependent enhancement of Ih. J Physiol 586:2157-2170. CrossRef Medline

Zhang H, Kiyatkin EA, Stein EA (1994) Behavioral and pharmacological modulation of ventral tegmental dendritic dopamine release. Brain Res 656:59-70. CrossRef Medline

Zweifel LS, Argilli E, Bonci A, Palmiter RD (2008) Role of NMDA receptors in dopamine neurons for plasticity and addictive behaviors. Neuron 59: 486-496. CrossRef Medline 